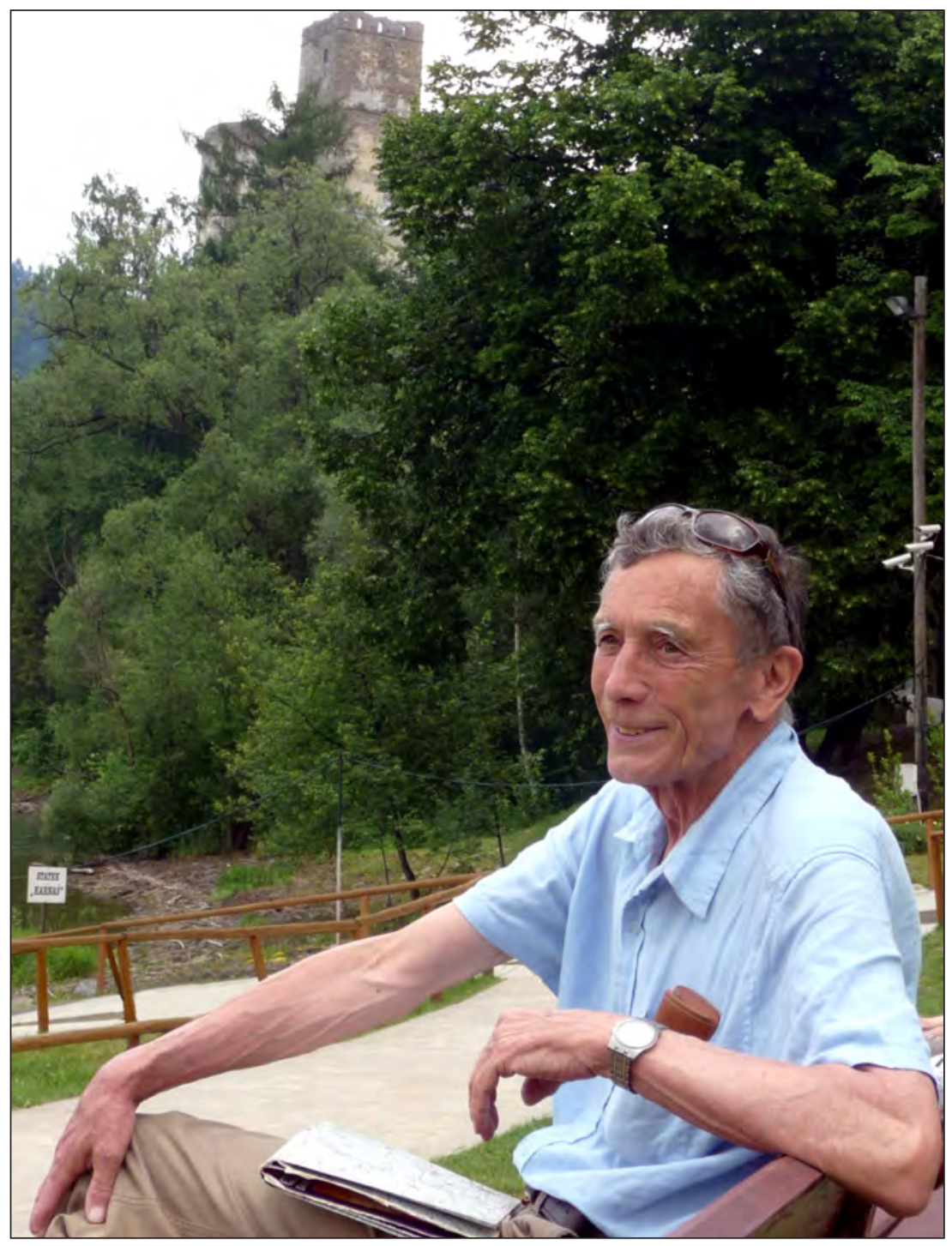

Profesor Roman Laskowski

1936-2014 
Maciej Grochowski

Instytut Języka Polskiego PAN, Kraków

Maciej.Grochowski@umk.pl

\section{POŻEGNANIE PROFESORA ROMANA LASKOWSKIEGO}

Dnia 21 czerwca 2014 r. odszedł od nas na zawsze, po ciężkiej chorobie, Profesor Roman Laskowski, Uczony światowego formatu, polonista, slawista, bohemista, teoretyk języka, współtwórca podstaw metodologicznych współczesnej lingwistyki, mających swe źródła w strukturalizmie sensu largo, jeden z najwybitniejszych językoznawców polskich drugiej połowy XX i początku XXI w. Był niekwestionowanym autorytetem w slawistyce międzynarodowej. Pożegnaliśmy Go 12 lipca na cmentarzu Rakowickim w Krakowie. Urna z prochami Zmarłego spoczęła w Alei Zasłużonych. Symbolika tego miejsca wiecznego spoczynku koresponduje z Jego wybitną osobowością.

Nie potrafię pisać o Romanie w czasie przeszłym, bo słyszę Go stale i widzę w dziesiątkach sytuacji oficjalnych i prywatnych, naukowych i towarzyskich. Nie potrafię uwierzyć, że niekończące się z Nim rozmowy i dyskusje, Jego prośby, sugestie, rady, Jego bezpośrednie, celne reakcje, pełne często gorzkiego humoru i delikatnej ironii, należą już do przeszłości... Był moim dobrym kolegą i serdecznym przyjacielem, znaliśmy się 44 lata. Byliśmy w tej samej Pracowni, najpierw Budowy Gramatycznej, a ostatnio Metodologii Gramatyki, przez kilka (z przerwami) dziesięcioleci: od samego początku mojej pracy naukowej do końca Jego dni... Odległość między Krakowem a Warszawą, a później Krakowem a Toruniem nie miała żadnego znaczenia. Najbardziej ceniłem w Nim skromność i otwartość, z każdego Jego kroku biła autentyczność. 
A stosunek Romana do nauki można by określić najkrócej, odwołując się do tytułu autobiografii Karla Poppera Nieustanne poszukiwania.

Roman Laskowski urodził się 17 lutego 1936 r. w miasteczku Komarno pod Lwowem, w rodzinie inteligenckiej. W kwietniu $1940 \mathrm{r}$., po wkroczeniu wojsk sowieckich do Komarna, został wywieziony wraz z rodziną do Kazachstanu (ojciec, aresztowany wcześniej przez NKWD, zmarł w obozie). Po nielegalnym powrocie do rodzinnego Komarna w 1945 r. i wyjeździe do Polski w 1946 r., rodzina Laskowskich osiedliła się w miasteczku Kietrz Śląski koło Raciborza, gdzie Roman w 1954 r. ukończył miejscowe liceum ogólnokształcące i zdał maturę. W latach 1954-1959 studiował filologię słowiańską (bohemistykę) na Uniwersytecie Jagiellońskim, uzyskując w 1959 r. tytuł zawodowy magistra. W latach 1960-1962 był zatrudniony na stanowisku asystenta i starszego asystenta w Komisji Językowej Śląskiego Instytutu Naukowego w Katowicach. Od 1962 r. aż do śmierci był pracownikiem naukowo-badawczym w placówkach Polskiej Akademii Nauk. W latach 1962-1968 pracował jako starszy asystent, a następnie adiunkt w Zakładzie Słowianoznawstwa PAN, w latach 1969-1973 w Zakładzie Języka Polskiego Instytutu Badań Literackich PAN, w Pracowni Budowy Gramatycznej, a od 1973 r., czyli od momentu utworzenia Instytutu Języka Polskiego PAN w Krakowie, w tym Instytucie, kolejno na stanowiskach adiunkta (do 1975), docenta (do 1981), profesora nadzwyczajnego (do 1996), profesora zwyczajnego (w latach 1996-1997), profesora ${ }^{1}$ (do 2010) i ponownie profesora zwyczajnego (w latach 2010-2014). W latach 1975-1985, a także 2001-2007 był kierownikiem Zakładu Teorii Języka i Współczesnego Języka Polskiego IJP PAN.

Stopień doktora nauk humanistycznych uzyskał na Uniwersytecie Jagiellońskim w 1967 r. na podstawie rozprawy Derywacja rzeczowników w dialektach laskich, przygotowanej pod kierunkiem profesora Alfreda Zaręby, a stopień doktora habilitowanego nauk humanistycznych w zakresie językoznawstwa w Instytucie Badań Literackich PAN w 1974 r. (utworzony rok wcześniej Instytut Języka Polskiego PAN nie miał jeszcze uprawnień do przeprowadzania habilitacji), na podstawie rozprawy Studia nad morfonologia wspótczesnego języka polskiego (Wrocław 1975). Monografia ta została wyróżniona nagrodą im. Kazimierza Nitscha w zakresie językoznawstwa, nadaną przez Wydział I Nauk Społecznych PAN. Tytuł naukowy profesora nadzwyczajnego ${ }^{2}$ otrzymał w $1981 \mathrm{r}$.

Prowadził zlecone zajęcia dydaktyczne w Wyższej Szkole Pedagogicznej w Rzeszowie (1969-1973), w Instytucie Filologii Słowiańskiej UJ (1971-1973, 1982/1983),

1 Na mocy Ustawy o PAN z 25 IV 1997 w Akademii było jedno stanowisko profesora, dwa stanowiska wprowadziła Ustawa o PAN z 30 IV 2010.

2 Według obowiązującej wówczas Ustawy z 31 III 1965 r. o stopniach naukowych i tytułach naukowych. 
jako visiting profesor na UW (1995/1996). W 1974 r. przebywał przez semestr na Uniwersytecie Ottawskim (University of Ottawa) jako guest researcher, prowadząc równocześnie wykład z podstaw metodologii badań językoznawczych. W latach 1973-1985 był zatrudniony w wymiarze połowy etatu na Uniwersytecie Śląskim w Katowicach, gdzie zorganizował Zakład Filologii Słowiańskiej i przez pewien czas był jego kierownikiem.

W 1985 r., po wygraniu konkursu, objął Katedrę Języków Słowiańskich na Uniwersytecie w Göteborgu, gdzie pracował jako profesor aż do przejścia na emeryturę w 2001 r. Po powrocie do Polski kontynuował pracę w Instytucie Języka Polskiego PAN, a ponadto był zatrudniony w Instytucie Dziennikarstwa i Komunikacji Społecznej UJ (w latach 2001-2008) oraz na Wydziale Kulturoznawstwa i Filologii Szkoły Wyższej Psychologii Społecznej w Warszawie (w latach 2008-2012).

Za krzewienie kultury polskiej w Szwecji został odznaczony w 1995 r. Krzyżem Kawalerskim Orderu Odrodzenia Polski.

Dorobek naukowy Profesora Romana Laskowskiego liczy ponad 150 publikacji i obejmuje 10 pozycji książkowych (nie licząc wydań uzupełnionych i poprawionych ani wznowień), w tym cztery we współautorstwie, redakcję i współredakcję kilkunastu prac zbiorowych opublikowanych w wydawnictwach krajowych i zagranicznych, artykuły i recenzje. Roman Laskowski publikował w kilkunastu krajach świata, w renomowanych międzynarodowych czasopismach i seriach wydawniczych (np. „Wiener Slawistischer Almanach”, „Zeitschrift für Slawistik”, „Revue des études slaves”, „Scando-Slavica”, Mouton de Gruyter, Verlag Otto Sagner, „Studia Slavica Oldenburgensia"). Jest autorem znaczących dla rozwoju lingwistyki nowatorskich propozycji metodologicznych, oryginalnych, poważnych prac empirycznych, a także doniosłych syntez. Jego prace wyróżniają się wnikliwością uzasadniania hipotez, ścisłością rozumowań i klarownością ich prezentacji.

Był Roman Laskowski Uczonym głębokim, wszechstronnym i nowoczesnym. Trudno znaleźć dziedzinę językoznawstwa, w której nie pozostawił trwałego śladu. Był przede wszystkim teoretykiem gramatyki, zwłaszcza morfologii ( $w$ równej mierze fleksji i słowotwórstwa), fonologii i morfonologii, ale wiele prac poświęcił także dialektologii, semantyce leksykalnej, zagadnieniom bilingwizmu, teorii tekstu, historii języka (był wydawcą tekstów staropolskich), rozwojowi myśli językoznawczej i filozofii języka. Wielkość obszaru, nad którym panował, doskonale oddaje tytuł zbioru dedykowanych Mu prac z okazji siedemdziesięciolecia urodzin: Od fonemu do tekstu (red. I. Bobrowski, K. Kowalik, Kraków 2006).

Większość prac analitycznych Romana Laskowskiego dotyczy polskiego materiału językowego, ma On jednak w swoim dorobku kilkanaście publikacji poświęconych innym językom słowiańskim (czeskiemu, macedońskiemu, słowackiemu, rosyjskiemu, 
ukraińskiemu). W badaniach Uczonego dominowały ujęcia synchroniczne. Jedną publikację książkową, której współautorem jest Józef Reczek, Glosy polskie rękopisu Sermones de tempore et de sanctis $\mathrm{Nr} X V_{32}$ biblioteki oo. dominikanów w Krakowie $z$ drugiej połowy $X V$ wieku (Wrocław 1968) i kilka ważnych artykułów poświęcił mechanizmom zmian językowych; np. The development of the category of gender in the Slavic languages, [w:] Linguistics across historical and geographical boundaries (red. D. Kastovsky, A. Szwedek, Berlin 1986), wspólnie z Wojciechem Rzepką i Wacławem Twardzikiem: Wpływ języka staroukraińskiego na średniowieczna polszczyznę kresową: „Rozmyślanie przemyskie”, [w:] Ukraina - między językiem a kulturą (red. B. Zinkiewicz-Tomanek, A. Fałowski, Kraków 2004).

Największe zasługi położył Roman Laskowski dla rozwoju morfologii; zob. przede wszystkim Gramatyka współczesnego języka polskiego. Morfologia (red. R. Grzegorczykowa, R. Laskowski, H. Wróbel, Warszawa 1984, ${ }^{2} 1998$, dodruk 1999), a ponadto ważne artykuły teoretyczno-metodologiczne: Uwagi o morfemie („Biuletyn Polskiego Towarzystwa Językoznawczego” 33, 1975), Bemerkungen zu den Wortarten („Zeitschrift für Slawistik" 20/5-6, 1975), Części mowy - problem syntaktyczny czy morfologiczny („Acta Universitatis Lodziensis. Folia Linguistica” 2, 1981), On the concept of the lexeme („Scando-Slavica” 33, 1987). Zbudował aparat pojęciowy współczesnej morfologii funkcjonalnej, teorię części mowy wraz z klasyfikacją leksemów polskich, opartą na kryteriach syntaktycznych, opracował całą fleksję języka polskiego (oprócz rzeczownika), scharakteryzował pełny zasób kategorii morfologicznych (werbalnych i nominalnych) współczesnej polszczyzny. Teoria morfologii, a w szczególności fleksji Romana Laskowskiego, była przedmiotem analizy, dyskusji i krytycznej refleksji wielu językoznawców (m.in. Mirosława Bańki, Andrzeja Bogusławskiego, Włodzimierza Gruszczyńskiego, Renaty Grzegorczykowej, Zygmunta Saloniego). Również propozycje klasyfikacji funkcjonalnej leksemów Jego autorstwa (w obu wydaniach Morfologii inne) stały się impulsem do nowych dociekań i kolejnych propozycji podziałów (m.in. autorstwa Jadwigi Wajszczuk, Henryka Wróbla, Zofii Zaron, Macieja Grochowskiego). $\mathrm{Z}$ tego wszystkiego zdają sprawę między innymi niektóre artykuły zawarte w tomie Językoznawstwo w Polsce. Kierunki badań i perspektywy rozwoju (red. M. Grochowski, Warszawa 2012), a zwłaszcza opublikowany w nim artykuł Romana Laskowskiego, Fleksja języka polskiego po sześćdziesięciu latach (i zamieszczona w nim bibliografia).

Profesor Roman Laskowski wniósł trwały wkład do badań teoretycznych nad kategoriami gramatycznymi czasu, trybu, strony, aspektu, przypadka, rodzaju i stopnia, a także do opisu tych kategorii w języku polskim na tle słowiańskim. Poszukiwał teoretycznych i empirycznych inspiracji i uzasadnień swoich tez w głębokich studiach z zakresu semantyki leksykalnej i semantyki zdania, a także teorii aktów mowy. Jest autorem znakomitych rozpraw składniowo-semantycznych na temat kategorii stopnia, trybu rozkazującego i jego zależności od aspektu: Semantyka trybu rozkazującego („Polonica” XIX, 1998), Peryferyjne funkcje polskiego imperatiwu, [w:] Anabasis. Prace ofiarowane Profesor Krystynie Pisarkowej (red. I. Bobrowski, Kraków 2003), 
pojęcia zmiany stanu i jego wykładników na różnych poziomach systemu gramatycznego i leksykalnego (do problematyki tej wracał Uczony w różnych okresach życia; por. Odimienne wyrażenia zmiany stanu w języku polskim („Slavica Slovaca” 12/3, 1977), Deverbative Verben der Zustandveränderung („Zeitschrift für Slawistik” 30, 1985), Expressions désignant le changement d'état en polonais („Scando-Slavica” 43, 1997), czasowników ruchu: Czasowniki ruchu liniowego (czasowniki przemieszczania) w perspektywie konfrontatywnej, [w:] Semantyka a konfrontacja językowa 2 (red. Z. Greń, V. Koseska-Toszewa, Warszawa 1999), „Wszystko idzie ku lepszemu” (czyli o tym, którędy chodzi polisemia), [w:] Amoenitates vel lepores philologiae (red. R. Laskowski, R. Mazurkiewicz, Kraków 2007) i przyimków temporalnych: Präpositionale Ausdrücke mit temporaler Funktion im Polnischen, [w:] Präpositionen im Polnischen (red. G. Hentschel, Th. Mentzel, Oldenburg 2003), Temporalne frazy przyimkowe o funkcji prospektywnej i retrospektywnej, [w:] Przysłówki i przyimki. Studia ze składni i semantyki języka polskiego (red. M. Grochowski, Toruń 2005). Osobne studia poświęcił analizie semantycznej czasowników epistemicznych: Rosyjskie „znat”, polskie „wiedzieć”, „znać”, [w:] Слово в тексте и в словаре (red. Л.Л. Иомдин, Л.П. Крысин, Москва 2оoо), Semantyka czasownika „pamiętać” („Biuletyn Polskiego Towarzystwa Językoznawczego" 64, 2008).

W dwutomowej monografii Derywacja rzeczowników w dialektach laskich. Część 1: Abstracta, collectiva, deminutiva, augmentativa. Część 2: Rzeczowniki z formantem $w$ funkcji przedmiotowej (Wrocław 1966, 1971), opartej na analizie obszernego materiału zebranego podczas badań terenowych na Śląsku, Morawach i na Słowacji, zaproponował koncepcję synchronicznego ujęcia słowotwórstwa oraz metody strukturalnego opisu faktów słowotwórczych w badaniach dialektologicznych. Zainteresowania Romana Laskowskiego dialektami śląskimi pochodzą jeszcze z okresu Jego asystentury w Śląskim Instytucie Naukowym. W 1965 r. opublikował artykuł System fonologiczny gwary wsi Moszna w powiecie krapkowickim („Zeszyty Naukowe UJ, Prace Językoznawcze" 15), w którym po raz pierwszy w Polsce została zastosowana teoria fonologicznych cech dystynktywnych Romana Jakobsona. W tym samym okresie, we wspólnym z Henrykiem Wróblem artykule Użycie paradygmatu w funkcji formantu słowotwórczego („Język Polski” 44, 1964), wprowadził do językoznawstwa polonistycznego pojęcie derywacji paradygmatycznej, powszechnie przyjęte w słowotwórstwie.

W latach 70. XX w. Roman Laskowski zaproponował model słowotwórstwa oparty na teorii gramatyki transformacyjno-generatywnej. Wprowadził nową wówczas funkcjonalną interpretację faktów słowotwórczych odwołującą się do tak zwanych przypadków głębokich Charlesa Fillmore’a: Struktura formalna a struktura semantyczna rzeczowników słowotwórczo podzielnych, („Studia Semiotyczne” 4, 1974), przedstawił krytyczną analizę rodzącej się w środowisku lingwistów amerykańskich teorii morfologii generatywnej, proponując jej trójpoziomowy model: Morfologia w gramatyce transformacyjno-generatywnej. W poszukiwaniu modelu opisu („Studia Gramatyczne” I, 1977). 
Rozwinął go po paru latach w artykule De la grammaire du lexique. Quelques problèmes de théorie de la formation des mots („Revue des études slaves” 56/2, 1984). Istotą tego modelu jest wyodrębnienie trzech typów mechanizmów generowania struktur słowotwórczych, obejmuje on reguły derywacji (mechanizm generowania semantycznej struktury wyrazu), reguły afiksacji (dobór środków morfologicznych realizujących tę strukturę) oraz reguły adaptacji (szeroko pojęte mechanizmy morfonologiczne).

Roman Laskowski jest autorem Polnische Grammatik (Warszawa, Leipzig 1972, ${ }^{2} 1979$ ) - zarysu gramatyki polskiej, który stanowi podstawowy podręcznik języka polskiego dla cudzoziemców na wielu uniwersytetach zachodnioeuropejskich, zwłaszcza niemieckich i skandynawskich.

Był pionierem fonologii generatywnej w Polsce. Jego monografia Studia nad morfonologia współczesnego języka polskiego (1975) jest opartym na generatywnej teorii języka opracowaniem polskiego systemu alternacji morfonologicznych, wprowadza mechanizm cyklicznego stosowania reguł fonologicznych - podejście, które wiązało derywację fonologiczną z morfemową strukturą wyrazu. Ten typ analizy stał się w następnym dziesięcioleciu podstawą generatywnej fonologii cyklicznej, a później fonologii leksykalnej. Wpływ prac Romana Laskowskiego na rozwój fonologii scharakteryzował w tomie jubileuszowym dedykowanym Uczonemu na siedemdziesięciolecie Jego urodzin Edmund Gussmann (Roman Laskowski and the development of Polish (morpho)phonology).

W latach 8o. XX w. podjął próbę analizy faktów morfonologicznych, a następnie morfologicznych za pomocą aparatu pojęciowego semiotyki Charlesa Peirce'a; zob. Semiotyczna funkcja alternacji morfonologicznych („Polonica” VI, 1981). Skierowało to uwagę Uczonego ku problemom teorii zmian językowych, zwłaszcza procesów rozwoju systemów morfologicznych. Poglądy Romana Laskowskiego na ten temat były bliskie teorii morfologii naturalnej, reprezentowanej w latach 8o. przez grupę językoznawców austriackich i niemieckich, do której należeli m.in. Wolfgang U. Dressler, Willi Mayerthaler, Oswald Panagl, Wolfgang U. Wurzel. Problematyce tej poświęcił trzy artykuły: What seems natural in inflectional morphology? („Studia Gramatyczne” VII, 1985), Semiotyczne uwarunkowania interferencji systemów fleksyjnych. Na materiale dialektów słowiańskich, [w:] Sprach- und Kulturkontakte im Polnischen (red. G. Hentschel, G. Ineichen, A. Pohl, München 1987), Mechanismen der morphologischen Adaptation deutscher Nomina im Polnischen, [w:] Deutsch-polnische Sprachkontakte (red. A. Pohl, A. de Vincenz, Köln, Wien 1987). Uzasadnił w nich tezę, iż jednym z dominujących mechanizmów, które determinują charakter zmian morfologicznych, jest tendencja do zachowania semiotycznej przejrzystości struktur językowych. Tezę tę zastosował w studiach z zakresu gramatyki historyczno-porównawczej języków słowiańskich: The development of the category of gender in the Slavic languages, [w:] Linguistics across historical and geographical boundaries (red. D. Kastovsky, A. Szwedek, Berlin 1986), The Systemic Prerequisites of the Development of the Declensional Patterns of the Slavic Languages. The Category of Gender („Scando-Slavica” 34, 1988). Przedstawił w nich 
zjawisko cyklicznego charakteru zmian językowych, które doprowadziły do ukształtowania się zróżnicowania kategorii rodzaju gramatycznego, znanego z dzisiejszych języków słowiańskich.

Nieobca była Profesorowi Romanowi Laskowskiemu problematyka teorii tekstu, poświęcił jej artykuły On Text Coherence, [w:] Polish Text Linguistics (red. L. Lönngren, Uppsala 1984), Tekst i jego struktura (kilka tez do zasad lingwistycznej analizy tekstu), [w:] Festskrift till Gunnar Jacobsson (Göteborg 1994). W pierwszym z nich uzasadnił tezę, że kooperacja uczestników komunikacji, oparta na kompromisie między wiedzą pozajęzykową nadawcy i odbiorcy, jest istotnym warunkiem możliwości ustalenia spójności tekstu. Na uwagę zasługuje też znakomity artykuł Romana Laskowskiego z historii metodologii językoznawstwa Wilhelm von Humboldt a filozofia języka XX wieku, [w:] Językoznawstwo historyczne i typologiczne. W 10o-lecie urodzin Profesora Tadeusza Milewskiego (red. L. Bednarczuk, W. Smoczyński, M. Wojtyła-Świerzowska, Kraków 2008). Omówił w nim miejsce relacji "język - myślenie - rzeczywistość" w koncepcji języka Wilhelma von Humboldta, a następnie wykazał zbieżności i różnice między poglądami tego wybitnego filozofa, antropologa i lingwisty z przełomu XVIII i XIX w. na naturę języka a podstawowymi tezami klasyków językoznawstwa strukturalnego, m.in. Ferdynanda de Saussure’a i Louisa Hjelmsleva.

Roman Laskowski jest autorem licznych artykułów hasłowych z zakresu fonetyki, fonologii, morfologii, leksykologii i leksykografii (o łącznej objętości około 10 arkuszy) w Encyklopedii języka polskiego (red. S. Urbańczyk, Wrocław 1978, ${ }^{2} 1991,{ }^{3} 1999,{ }^{4} 2004$ wydanie trzecie i czwarte również pod red. M. Kucały), a ponadto artykułów z zakresu fonologii i morfologii (także o objętości około 10 arkuszy) w Encyklopedii językoznawstwa ogólnego (red. K. Polański, Wrocław 1994, $\left.{ }^{2} 1999,{ }^{3} 2004\right)$.

W latach 90. XX w. na Uniwersytecie w Göteborgu Profesor Roman Laskowski prowadził badania nad przyswajaniem języka polskiego przez dzieci polskich imigrantów w Szwecji. Kierował zespołowymi projektami badawczymi „Dzieci polskich imigrantów w Szwecji” oraz „Szwedzkie złożenia z głównym członem werbalnym oraz ich semantyczne odpowiedniki w języku polskim", w ramach których zgromadzony został obszerny materiał językowy w postaci nagrań wypowiedzi mówionych ponad stu osób (w wieku od pięciu do szesnastu lat, urodzonych w Szwecji bądź w Polsce i zamieszkałych w Szwecji co najmniej pięć lat). Efektem Jego pionierskich prac z tego zakresu jest kilkanaście artykułów, w których obok socjologicznych i psychologicznych uwarunkowań przyswajania języka ojczystego omawia wpływ szwedzkiego systemu językowego na kształtowanie się idiolektów dzieci polskich; zob. np. Społeczne uwarunkowania zachowania języka polskiego przez drugie pokolenie polskich imigrantów w Szwecji (Uwagi wstępne), [w:] Warianty języka (red. S. Gajda, Opole 1991), The system internal and external factors in the acquisition of Polish by immigrant children in Sweden, [w:] Multilingualism in the Nordic Countries and Beyond (red. K. Herberts, Ch. Laurén, Åbo 1991), The Endangered Language: The Acquisition of the Case System by Polish Children in Sweden), [w:] Studies in Polish 
Morphology and Syntax (red. G. Hentschel, R. Laskowski, München 1993). Podsumowaniem wyników badań nad językiem dzieci polskiej diaspory w Szwecji jest monografia Romana Laskowskiego Język w zagrożeniu. Przyswajanie języka polskiego $w$ warunkach polsko-szwedzkiego bilingwizmu (Kraków 2009). Ujawnił w niej nie po raz pierwszy, że do Jego podstawowych zainteresowań językoznawczych należała morfologia i jej aparat pojęciowy. Więcej niż 1/3 objętości monografii poświęcił kategorii przypadka w idiolektach dzieci polskich, pokazując, jaki wpływ ma brak tej kategorii w języku szwedzkim na zakłócenia w jej przyswajaniu (aż do nieprzyswajania) w polszczyźnie.

Roman Laskowski przez kilka dziesięcioleci uczestniczył w polskim i międzynarodowym życiu naukowym, był jego utalentowanym animatorem i sprawnym organizatorem. Ceniono Jego mądrość, niezależność, odwagę. Darzono Go szacunkiem. Wybierano Go do znaczących gremiów reprezentujących naukę. W 1990 r. został wybrany na członka korespondenta, a w 2013 r. na członka czynnego Polskiej Akademii Umiejętności, w tym samym roku został sekretarzem Wydziału I Filologicznego PAU i sprawował tę funkcję aż do śmierci. Przez wiele kadencji był członkiem Komitetu Językoznawstwa i Komitetu Słowianoznawstwa PAN. Był członkiem trzech komisji międzynarodowych afiliowanych przy Międzynarodowym Komitecie Slawistów: Komisji Budowy Gramatycznej Języków Słowiańskich (od 1974 r., w latach 1976-1986 był sekretarzem naukowym Komisji), Komisji Fonetyki i Fonologii Języków Słowiańskich (w latach 1979-1987), Komisji Słowotwórstwa Języków Słowiańskich (od 1994 r.). Wybrano Go do Europejskiego Towarzystwa Językoznawczego (SLE), Czeskiego Towarzystwa Językoznawczego, Królewskiego Towarzystwa Naukowego w Göteborgu (Kungliga Vetenskaps- och Vitterhetssamhället i Göteborg), był członkiem honorowym Polskiego Towarzystwa Językoznawczego.

Roman Laskowski wygłaszał wykłady gościnne na kilkudziesięciu uniwersytetach europejskich, m.in. w Niemczech, Austrii, Szwecji, Danii, Norwegii, Francji, Wielkiej Brytanii, w Czechach, na Słowacji. Uczestniczył w dziesiątkach międzynarodowych kongresów, konferencji i sympozjów językoznawczych w większości krajów Europy, był organizatorem wielu konferencji międzynarodowych w Polsce i Szwecji.

W latach 70. i 8o. XX w., w okresie prac nad Gramatyka wspótczesnego języka polskiego (tzw. żółtą gramatyką), Profesor Roman Laskowski był spiritus movens licznych dyskusji, polskich i międzynarodowych, a także wielu przedsięwzięć wydawniczych. Należał do kilkuosobowego grona założycieli i współredaktorów wydawanego okresowo w Instytucie Języka Polskiego PAN pisma „Studia Gramatyczne” (w latach 1977-1995 opublikowano jedenaście tomów). Wydał ponadto zbiory O predykacji (Wrocław 1974) i Kategorie gramatyczne grup imiennych w języku polskim (Wrocław 1975); pierwszy wspólnie z Alicją Orzechowską. 
Z inicjatywy Romana Laskowskiego powstało w 2004 r. pierwsze anglojęzyczne czasopismo poświęcone językowi polskiemu „Studies in Polish Linguistics”. Rada Naukowa IJP PAN powołała Go na pierwszego redaktora naczelnego pisma; był nim do tomu 7., wydanego w 2012 r. (od tomu 5. wraz z Elżbietą Tabakowską był współredaktorem pisma). Od 2006 r. był redaktorem naczelnym „Biuletynu Polskiego Towarzystwa Językoznawczego". Należał do rad redakcyjnych kilku czasopism językoznawczych: „Polonica”, „Rocznik Slawistyczny”, „Linguistica Copernicana”, „Studies in Polish Linguistics”, „Cognitive Studies / Études Cognitives”, „Русский язык”.

U schyłku PRL-u Roman Laskowski dzielił czas na pracę naukowo-badawczą i działalność opozycyjną. Od momentu powstania NSZZ „Solidarność” zaangażował się w budowanie struktur organizacyjnych związku w Polskiej Akademii Nauk. Został wiceprzewodniczącym Komisji Zakładowej „Solidarności” Oddziału PAN w Krakowie oraz zastępcą przewodniczącego Ogólnopolskiej Komisji Porozumiewawczej NSZZ "Solidarność" w PAN, odpowiedzialnym między innymi za przygotowanie projektu reformy PAN, a także za doprowadzenie do zadośćuczynienia szykanowanym pracownikom PAN. Po ogłoszeniu stanu wojennego włączył się w prace podziemnych struktur związku. Był jednym z tych działaczy, którzy doprowadzili do powstania podziemnej Tymczasowej Komisji Porozumiewawczej NSZZ „Solidarność”. Był współzałożycielem i współredaktorem „Biuletynu Małopolskiego”, organu prasowego Regionalnej Komisji Wykonawczej Regionu Małopolska, a od jesieni 1983 r. Regionalnego Komitetu „Solidarność” Małopolska. Współpracował także z podziemnym „Miesięcznikiem Małopolskim”. Stworzył Radę Programową RKW, kierował tzw. grupą opinii i analiz, był łącznikiem merytorycznym RKW z Tymczasową Komisją Koordynacyjną NSZZ „Solidarność". Po wyjeździe do Szwecji w 1985 r. pozostawał w kontakcie z Biurem Zagranicznym „Solidarności” w Brukseli. W działalności konspiracyjnej posługiwał się pseudonimem „Kamil”.

Profesor Roman Laskowski pozostawił ogromny dorobek o nieprzemijającej wartości i wielkim ciężarze gatunkowym. Dorobek ten ma już swoje trwałe miejsce w historii językoznawstwa, w najnowszych dziejach nauk humanistycznych. Zasługuje na odrębną, gruntowną, wnikliwą analizę. Niniejszy szkic stanowi zaledwie bardzo ogólne wprowadzenie do takiej analizy.

Był też Roman Laskowski niemal do ostatnich chwil uczestnikiem, organizatorem i współtwórcą życia naukowego wielu instytucji. Był recenzentem i krytykiem przemian w szkolnictwie wyższym i nauce. Nigdy nie ukrywał swojego zdania nie tylko w sprawach merytorycznych, ale również tych mających szerszy wymiar społeczny 
i prawny. Był Człowiekiem prawdziwie zatroskanym o przyszłość badań naukowych w Polsce, o merytoryczną ocenę ich wyników, nie były Mu także obojętne losy milionów dzieci polskiej diaspory, ich język ojczysty, ich polskość. Swojej trosce dał wyraz w jakże odmiennych pod każdym względem artykułach opublikowanych w ostatnim roku życia. Prace te łączy wyrażone w nich pragnienie dobra: dobra nauki, dobra dzieci, dobra Polaków.

Pozostawił nam Roman Laskowski dwa przesłania. Na zakończenie oddaję Mu głos:

Dokładnie 65 lat temu Jerzy Kuryłowicz, wybitny językoznawca, ogłosił artykuł „Le problème du classement des cas”, który na dziesięciolecia ustalił w literaturze światowej sposób interpretacji gramatycznej kategorii przypadka. Gdyby w tym samym polskim czasopiśmie językoznawczym ten sam autor opublikował swój artykuł dzisiaj, byłby zapewne dumny, uzyskawszy 6 punktów. Oczywiście, to samo czasopismo w 1949 roku i w roku 2014 nie jest tym samym czasopismem. A jednak... Chyba niewiele więcej warto dodawać do obowiązującej oceny wartości naukowej publikacji (i ich autorów oraz macierzystych instytucji) opartej tylko na kryteriach ilościowych. Szkody, jakie humanistyce przyniesie, już przynosi, narzucona przez ministerstwo wizja nauki, której głównym celem nie jest „poszukiwanie prawdy”, lecz pogoń za wymyślonymi przez urzędników punktami, staną się niebawem niepowetowane. Dewastacja dyskursu naukowego już trwa (R. Laskowski, Drogi i bezdroża parametryzacji, [w:] Oceny nauki, red. Szczepan Biliński, Kraków 2014, s. 95).

Dzieciom diaspory należy zapewnić prawidłowy rozwój w warunkach życia w dwu językach, w dwu kulturach, uświadomić im, że znajomość języka i kultury ojczystej rodziców nie jest obciążeniem, lecz bogactwem sprzyjającym rozwojowi intelektualnemu dziecka [...]. Życie w dwu językach, w dwu różnych kulturach czyni dziecko człowiekiem otwartym na świat, uświadamia jego różnorodność, uczy tolerancji, rozumienia „innego" i - co niezwykle ważne - akceptacji własnej odrębności, prawa do bycia „innym” niż inni „inni” w wielokulturowym świecie (R. Laskowski, Język a tożsamość etniczna. Kształtowanie siępoczucia narodowego młodej polskiej diaspory w warunkach wielokulturowości, „LingVaria” nr 2 (16), 2013, s. 84, 88). 